\title{
ISOLASI SENYAWA EKSTRAK ETIL ASETAT DAUN TUMBUHAN BERENUK (Crescentia cujete $\mathrm{L}$.)
}

\author{
Afdhil Arel ${ }^{1, *}$ dan Wida Ningsih ${ }^{2}$ \\ ${ }^{1}$ Program Studi Farmasi, Fakultas Farmasi, Universitas Muhammadiyah Sumatera Barat \\ ${ }^{2}$ Program Studi Farmasi Klinis, Fakultas Kedokteran, Universitas Baiturrahmah \\ Email: *afdhil.arel@yahoo.com \\ *Corresponding author
}

\begin{abstract}
Abstrak
Berenuk merupakan tanaman perdu tropis yang berkhasiat sebagai obat berbagai penyakit. Daun berenuk dalam pengobatan tradisional digunakan untuk mengobati luka baru dan menurunkan hipertensi. Pada penelitian ini dilakukan identifikasi dan isolasi pada daun berenuk (Crescentia cujete L.). Isolasi dilakukan dengan cara ekstraksi maserasi menggunakan pelarut etil asetat yang menghasilkan ekstrak kental daun berenuk. Pemisahan untuk senyawa ekstrak kental etil asetat dilakukan menggunakan kromatografi kolom kemudian dimonitor menggunakan Kromatografi Lapis Tipis (KLT). Pola fraksi noda yang sama digabungkan pada hasil pemisahan dengan KLT. Karakterisasi senyawa dilakukan dengan spektrofotometer UV-Vis dengan panjang gelombang maksimal $403 \mathrm{~nm}$, spektrofotometer IR memberikan pita serapan pada bilangan gelombang $1734.82 \mathrm{~cm}^{-1}, 1236.42 \mathrm{~cm}^{-1}, 2983.39 \mathrm{~cm}^{-1}, 3566.05 \mathrm{~cm}^{-1}$, dan titik leleh $194-199^{0} \mathrm{C}$. Senyawa hasil isolasi dari ekstrak etil asetat daun berenuk (Crescentia Cujete L) yang telah dilakukan, diduga adalah golongan flavonoid berupa amorf yang berwarna hijau muda, tidak berbau, dengan rendemen $1,04 \%$.
\end{abstract}

Kata kunci: Daun Berenuk; Isolasi; Kromatografi Kolom

\begin{abstract}
Berenuk is a tropical herbaceous plant that is efficacious as a medicine for various diseases. Berenuk leaves in traditional medicine are used to treat new wounds and reduce hypertension. In this study, identification and isolation of berenuk (Crescentia cujete L.) leaves was carried out. Isolation was carried out by maceration extraction using ethyl acetate as a solvent which produced a thick extract of berenuk leaves. Separation of the thick extract compound ethyl acetate was carried out using column chromatography and then monitored using Thin Layer Chromatography (TLC). The pattern of the same stain fraction was combined in the results of the separation by TLC. The characterization of the compounds was carried out by UV-Vis spectrophotometer with a maximum wavelength of $403 \mathrm{~nm}$, IR spectrophotometer gave absorption bands at wave numbers $1734.82 \mathrm{~cm}-1,1236.42 \mathrm{~cm}-1,2983.39 \mathrm{~cm}-1,3566.05 \mathrm{~cm}-1$, and melting point 194-199 C. The compound isolated from the ethyl acetate extract of the leaves of berenuk (Crescentia Cujete L) that has been carried out is suspected to be a flavonoid group in the form of an amorphous light green color, odorless, with a yield of $1.04 \%$.
\end{abstract}

Keywords : Crescentia cujete L, isolation, Chromatography column 


\section{PENDAHULUAN}

Indonesia merupakan negara yang kaya akan sumber daya alam hayati, diantaranya dengan dimilikinya hutan basah yang ditumbuhi dengan tanaman yang berkhasiat obat. Penggunaan tanaman obat atau lebih dikenal dengan obat tradisional sebenarnya sudah merupakan warisan nenek moyang (Kusmiyati et al, 2011). Indonesia banyak memiliki tumbuhan berkhasiat obat, namun belum banyak dikaji secara ilmiah. Tumbuhan dalam pengobatan tradisional diperlukan perlu ditunjang dengan kajian ilmiah sehingga dapat dipastikan kebenaran khasiatnya dan diperoleh data ilmiah yang pasti mengenai komponen aktif dari bahan nabati tersebut (Departemen Kesehatan Republik Indonesia, 2000).

Kandungan senyawa yang pada bahan alam (tumbuhan) terdiri dari senyawa metabolit primer dan metabolit sekunder. Senyawa metabolit primer merupakan kandungan yang digunakan oleh tumbuhan sebagai penghasil energi seperti karbohidrat, protein dan lemak. Sedangkan senyawa metabolit sekunder merupakan senyawa kimia yang mempunyai kemampuan sebagai pelindung tumbuhan dari gangguan penyakit dan serangan hama. Senyawa ini dapat digolongkan dalam beberapa jenis senyawa seperti terpenoid, steroid, flavonoid dan alkaloid (Sjamsul, 1986).

Suatu cara untuk mendapatkan senyawa kimia aktif, diperlukan proses ekstraksi terlebih dahulu, ekstraksi bertingkat akan menghasilkan senyawa tertentu yang terekstrak secara spesifik pada tiap pelarut yang digunakan (Permadi et al, 2012). Ekstraksi dengan pelarut seperti air, metanol, etanol, etil asetat dan n-heksan dapat memisahkan senyawasenyawa yang penting dalam suatu bahan (Sudarmadji et al, 1998).

Etil asetat merupakan jenis pelarut yang bersifat semi polar, cocok digunakan untuk menarik senyawa seperti flavonoid, alkaloid, dan fenolik (Djamal, 2010). Maka dengan menggunakan etil asetat, diharapkan pelarut ini dapat menarik sempurna senyawa kimia yang bersifat semi polar. Salah satu cara ekstraksi menggunakan pelarut dengan cara dingin seperti maserasi, Maserasi merupakan salah satu cara ekstraksi yang sederhana dengan merendam serbuk dalam pelarut tertentu dengan beberapa kali pengadukan atau pengocokan pada temperatur ruangan (Departemen Kesehatan Republik Indonesia, 2000).

Salah satu tanaman yang berpotensi dikembangkan dalam dunia pengobatan adalah berenuk (Crescentia cujete Linn). Berenuk merupakan tanaman perdu tropis yang berkhasiat sebagai obat berbagai penyakit. Daun berenuk secara pengobatan tradisional telah digunakan sebagai pengobatan luka baru dan menurunkan tekanan darah. Daun mudanya digunakan sebagai pengkompres dengan cara ditumbuk untuk sakit kepala dan luka. Sedangkan daging buahnya digunakan untuk mengobati diare, flu, bronkhitis, batuk, asma, dan uretritis (Heyne 1987).

Penelitian ilmiah mengenai berenuk masih sangat jarang, namun tanaman ini memiliki potensi yang cukup menjanjikan sebagai obat herbal (Kusuma et al, 2014). Salah satunya adalah penelitian dilakukan menunjukan bahwa ekstrak etanol daun berenuk memiliki daya anti bakterial yang efektif menghambat pertumbuhan bakteri Shigella dysentriae (Ardianti \& Kusnadi, 2014). Hasil penelitian yang dilakukan di Fakultas Farmasi UMP juga menunjukkan bahwa ektrak etanol daun berenuk dengan konsentrasi $60 \%$ dan $80 \%$ secara signifikan mampu mempercepat penghentian pendarahan luar mencit serta mempunyai aktivitas antiradang (anti inflamasi) pada mencit secara in vivo dengan dosis 1680, 3360 dan $6720 \mathrm{mg} / \mathrm{kg}$ BB (Kusuma et al, 2012).

Berdasarkan hal tersebut dapat diketahui bahwa daun tumbuhan berenuk memiliki manfaat dalam pengobatan, maka peneliti tertarik untuk melakukan isolasi lebih lanjut terhadap tumbuhan berenuk (Crescentia cujete,L), dengan menggunakan metode 
ekstraksi maserasi bertingkat menggunakan pelarut n-heksan dan etil asetat, yang bertujuan agar mengetahui kandungan senyawa kimia aktif yang terdapat dalam daun tumbuhan berenuk.

\section{METODE PENELITIAN}

Penelitian ini merupakan penelitian eksperimental yang dilakukan di Laboratorium Bahan Alam. Beberapa tahap pengerjaan yaitu :

\section{Pengambilan Sampel}

Sampel yang digunakan adalah daun segar dari tumbuhan berenuk (Crescentia cujete L.) sebanyak $3 \mathrm{~kg}$ sampel segar yang diperoleh di Nagari Tandikat Barat Kecamatan Patamuan Kabupaten Padang Pariaman, Sumatera Barat.

\section{Pembuatan Ekstrak Etil Asetat Daun Berenuk (Crescentia cujete L.)}

Daun berenuk sebanyak $3 \mathrm{~kg}$ dibersihkan dari ranting dan pengotornya dengan dicuci menggunakan air bersih, dikering anginkan, lalu dipotong kecil, kemudian sampel dimaserasi dengan cara sampel dimasukkan kedalam botol berwarna gelap direndam selama 3 kali 24 jam dengan suhu kamar menggunakan pelarut n-heksan sambil sesekali di aduk. Lakukan penyaringan dengan kertas saring kemudian ampasnya dimaserasi lagi dengan etil asetat, lalu saring dengan kertas saring. Selanjutnya maserat diuapkan dengan menggunakan rotary evaporator hingga diperoleh ekstrak kental. Jadi, yang diambil di sini adalah ekstrak kental etil asetat. ${ }^{1}$

\section{Evaluasi Ekstrak Etil Asetat Daun Berenuk (Cresentia cujete L.) (Harborne, 1987)}

Uji karakterisasi meliputi pemeriksaan organoleptis, penentuan rendemen dan uji fitokimia. Pengujian fitokimia dilakukan dengan menggunakan beberapa pengujian meliputi uji flavonoid, fenolik, saponin, terpenoid, dan alkaloid. Ekstrak kental etil asetat daun tumbuhan berenuk dimasukan ke dalam tabung reaksi, ditambahkan aquadest sebanyak $5 \mathrm{ml}$ dan $5 \mathrm{ml}$ kloroform asetat, dikocok lalu dibiarkan sampai terbentuk 2 lapisan air dan kloroform. Lapisan air digunakan pemeriksaan: flavonoid, fenolik, saponin dan lapisan Kloroform untuk pemeriksaan: terpenoid, steroid dan alkaloid.

a. Uji flavonoid (Metode "Sianidin Test")

Diambil lapisan air 1-2 tetes, diteteskan pada plat tetes lalu tambahkan serbuk Mg dan $\mathrm{HCl}(\mathrm{p})$, terbentuknya warna merah menandakan adanya flavonoid.

b. Uji Fenolik

Diambil lapisan air 1-2 tetes, lalu diteteskan pada plat penetes dan tambahkan pereaksi

$\mathrm{FeCl} 3$, apabila terbentuknya warna biru menandakan adanya kandungan fenolik.

c. Uji Saponin

Diambil lapisan air dikocok kuat-kuat dalam tabung reaksi, terbentuk busa yang permanen ( \pm 15 menit) menunjukan adanya saponin.

d. Uji Terpenoid dan Steroid (Metode "Simes")

Ambil sedikit lapisan kloroform kemudian ditambahkan dengan norit, dimasukkan dalam pipet tetes yang ujungnya diberi kapas lalu dipindahkan ke dalam plat tetes dan dibiarkan mengering, selanjutnya ditambahkan $\mathrm{H} 2 \mathrm{SO} 4$ (p) 2 tetes, ditambahkan asam 
asetat anhidrat, apabila terbentuknya warna biru ungu menandakan adanya steroid, sedangkan bila terbentuk warna merah menunjukkan adanya terpenoid.

e. Uji Alkaloid (metode "Culvenore-Fristgerald")

Diambil lapisan kloroforom ditambahkan $10 \mathrm{ml}$ kloroforom amoniak 0,05 N, ditambahkan beberapa tetes $\mathrm{H} 2 \mathrm{SO} 42 \mathrm{~N}$ kemudian dikocok dan dibiarkan memisah. Pada lapisan asam ditambahkan reagen mayer beberapa tetes, adanya kabut putih hingga gumpalan putih menandakan reaksi positif alkaloid.

\section{Isolasi Senyawa Utama (Arel et al, 2016)}

Sampel disiapkan secara preadsorpsi dengan melarutkan sampel dalam etil asetat dan ditambah silika gel dengan perbandingan 1:1. Sampel yang dicampurkan dengan silika kemudian diuapkan menggunakan rotary evaporator sehingga diperoleh bentuk serbuk. Setelah silika gel menyatu membentuk serbuk, kemudian dimasukkan kedalam kolom yang telah disiapkan. Elusi dilakukan dengan menggunakan fasa gerak sebanyak $100 \mathrm{~mL}$ tiap elusi dengan variasi polaritas yang ditingkatkan secara bertahap yaitu pelarut heksan, heksan - etil asetat, etil asetat, etil asetat-metanol, dan methanol Perpindahan pengelusi ke tingkat yang lebih polar dilakukan jika noda yang ditampung sudah tidak memiliki noda lagi yang dimonioring dengan lampu UV 254 dan 366. Hasil kromatografi ditampung dengan vial. Fraksi dengan Rf yang sama digabung. Hasil penggabungan ekstrak tersebut dilihat nodanya dengan KLT. Pola noda yang baik, maka ekstrak tersebut yang dilakukan rekristalisasi dan identifikasi selanjutnya.

\section{Karakterisasi Senyawa Hasil Isolasi}

Pemeriksaan yang dilakukan pada senyawa hasil isolasi adalah pemeriksaan organoleptis, diamati warna, bau, dan bentuk dari senyawa hasil isolasi tersebut. Selain itu dilakukan pula uji sifat fisika, kimia dan fisiko kimia.

Uji sifat kimia dengan menggunakan beberapa pereaksi yaitu : pereaksi $\mathrm{FeCl}_{3}$, lieberman-Bouchard, dragendor, dan $\mathrm{HCl} / \mathrm{Mg}$. Uji sifat fisika yaitu dengan melakukan uji kelarutan dan titik leleh.

Pada pengujian titik leleh sampel dimasukkan dengan cara mentotolkan kedalam pipa kapiler. Setelah melting point dihidupkan, Dipasang termometer pada alat uji titik leleh (melting point). Pipa kapiler sampel diletakkan pada lubang alat melting point ( di atas termometer). Amati perubahan zat yang terdapat dalam kapiler sampel. Temperatur pada saat zat mulai mencair atau meleleh sampai zat habis meleleh secara keseluruhan dicatat temperaturnya (Priyanto, 2013). Pada pengujian sifat fisiko kimia dilakukan uji Spektrofotometer UV-Visible dan Spektrofotometri Inframerah

Pemeriksaan spektrum UV dilakukan dengan menggunakan alat spektrofotometer UV-Visibel. Sampel dilarutkan dengan methanol metanol dalam labu ukur, lalu dimasukkan dalam kuvet, kemudian diukur serapannya untuk melihat panjang gelombang maksimum. Pemeriksaan Spektrofotometer Inframerah diukur dengan cara kira-kira $1 \mathrm{mg}$ sampel diletakkan pada sample pan, kemudian diukur serapannya untuk melihat gugus fungsi.

\section{HASIL DAN PEMBAHASAN}

Sampel daun berenuk di maserasi terlebih dahulu dengan n-heksan dilanjutkan maserasi dengan etil asetat. Maserasi dilakukan selama 3 × 24 jam dengan sesekali di aduk, pengadukan dilakukan untuk mempercepat masuknya pelarut kedalam sampel sehingga komponen-komponen kimia didalamnya cepat terlarut. Pelarut diuapkan secara 
in-vacuo. Pada proses ekstraksi diperoleh ekstrak kental etil asetat daun berenuk sebanyak 8,98 gram.

Ekstrak kental etil asetat yang diperoleh dilakukan identifikasi dengan pengamatan organoleptis yang meliputi warna, bau, dan bentuk. Warna dari ekstrak kental daun Crescentia cujete Linn adalah hijau pekat, berbau khas, bentuk nya kental. Selain itu dilakukan uji fitokimia. Hasil dari uji fitokimia ini menunjukkan bahwa senyawa yang terdapat pada ekstrak kental tersebut adalah positif flavonoid, fenolik, alkaloid, dan steroid.

Isolasi senyawa daun berenuk ini dilakukan menggunakan kromatografi kolom dengan fase diam silika gel dengan sistem eluen SGP. Ekstrak kental daun berenuk sebanyak 5 gram. Hasil kromatografi kolom ditampung dengan vial. Tiap fraksi dimonitor dengan KLT dan noda dideteksi menggunakan lampu UV pada panjang gelombang $254 \mathrm{~nm}$. Fraksi dengan Rf yang sama digabung,. Proses kromatografi kolom. Dari hasil penggabungan fraksi tersebut dicek kembali dengan KLT, hingga didapat satu fraksi. Senyawa tersebut memberikan noda tunggal pada plat KLT di bawah lampu UV $254 \mathrm{~nm}$, menggunakan eluen n-heksan : etil asetat (6:4), dan nilai $\mathrm{Rf}=0,48 \mathrm{~cm}$. Selanjutnya dilakukan pemeriksaan fitokimia dengan menggunakan pereaksi $\mathrm{HCl} / \mathrm{Mg}$ menunjukkan perubahan warna merah. Pemeriksaan titik leleh senyawa hasil isolasi di dapatkan suhu $194-199^{\circ} \mathrm{C}$. Pada pemeriksaan spektrofotometer UV-Vis memperlihatkan adanya serapan maksimum pada panjang gelombang maksimum $403 \mathrm{~nm}$ dengan adsorban 0,416 .

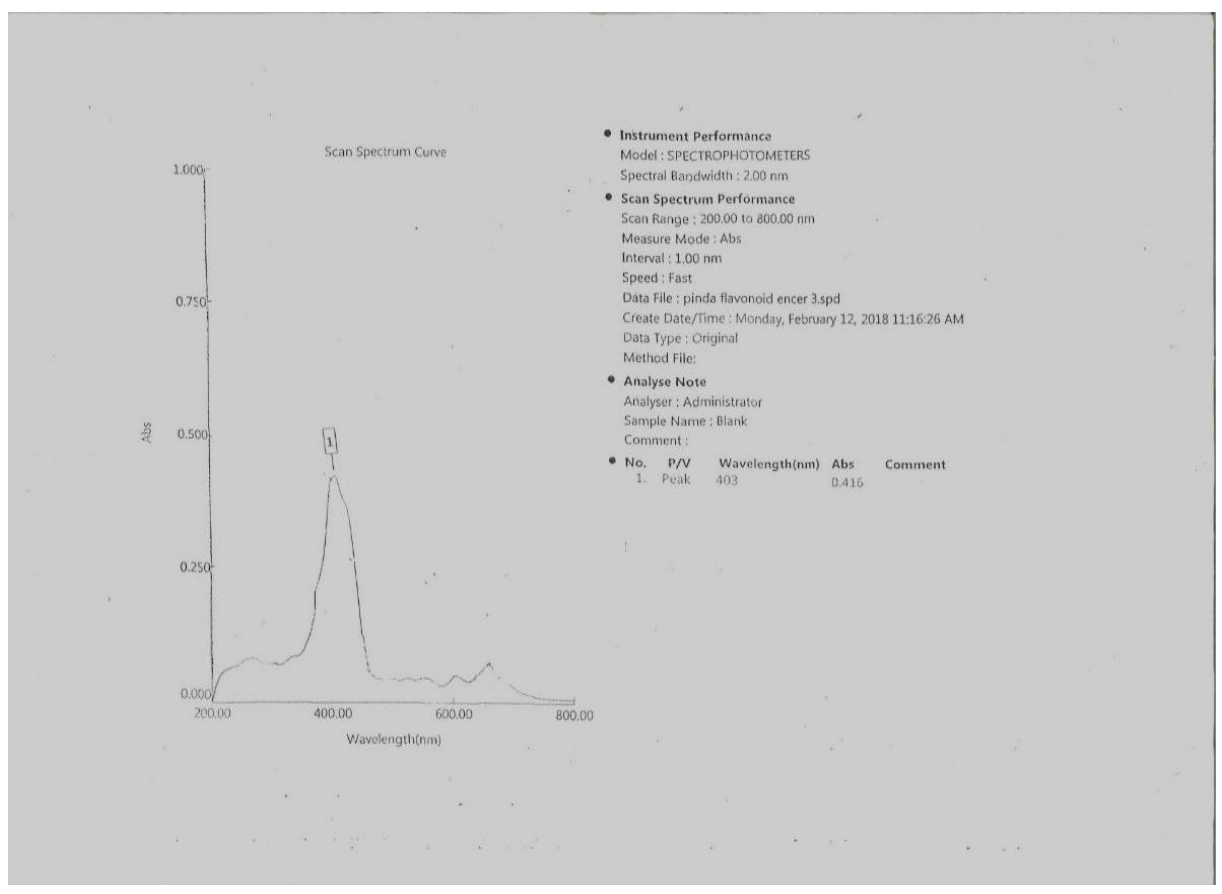

Gambar 1. Spektrum Spektroskopi UV-Vis Hasil Isolasi 


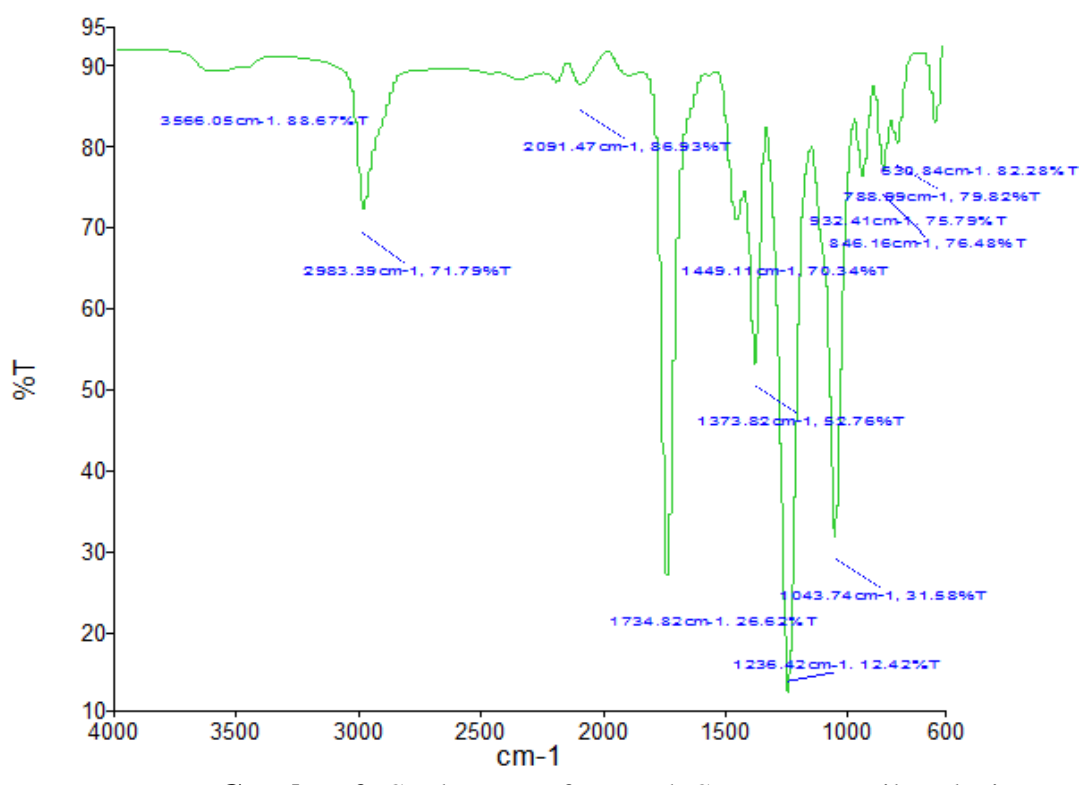

Gambar 2. Spektrum Inframerah Senyawa Hasil Isolasi

Tabel 1. Data Spektrum Serapan Sinar Inframerah Senyawa Isolasi

\begin{tabular}{c|c|c} 
No. & $\begin{array}{c}\text { Bilangan Gelombang } \\
\text { Puncak Serapan }\left(\mathbf{c m}^{-1}\right)\end{array}$ & Gugus Fungsi \\
\hline 1. & $1734.82 \mathrm{~cm}^{-1}$ & $\mathrm{C}=\mathrm{O}$ \\
\hline 2. & $1236.42 \mathrm{~cm}^{-1}$ & $\mathrm{C}-\mathrm{O}$ \\
\hline 3. & $2983.39 \mathrm{~cm}^{-1}$ & $\mathrm{C}-\mathrm{H}$ \\
\hline 4. & $3566.05 \mathrm{~cm}^{-1}$ & $\mathrm{O}-\mathrm{H}$
\end{tabular}

Senyawa hasil isolasi menggunakan IR menunjukkan adanya gugus $\mathrm{O}-\mathrm{H}$ dengan bilangan gelombang $3566.05 \mathrm{~cm}^{-1}$, C-H dengan bilangan gelombang $2983.39 \mathrm{~cm}^{-1}$, gugus $\mathrm{C}=\mathrm{O}$ dengan bilangan gelombang $1734.82 \mathrm{~cm}^{-1}$, dan gugus $\mathrm{C}-\mathrm{O}$ pada bilangan gelombang $1236.42 \mathrm{~cm}^{-1}$.

\section{KESIMPULAN}

Senyawa hasil isolasi dari ekstrak etil asetat daun berenuk (Crescentia Cujete L) yang telah dilakukan, diduga adalah golongan flavonoid berupa amorf yang berwarna hijau muda, tidak berbau, dengan rendemen 1,04\%. Disarankan kepada peneliti selanjutnya untuk mencari nama senyawa kimia yang telah diisolasi menggunakan alat lainnya.

\section{REFERENSI}

Ardianti, A., \& Kusnadi, J. (2014). Ekstraksi Antibakteri dari Daun Berenuk (Crescentia cujete Linn.) Menggunakan Metode Ultrasonik. Pangan Dan Argoindustri, 2(2), $28-35$. 
Arel, A., Dira, \& Setiawati, A. (2016). Isolasi Senyawa Utama Kulit Batang Tumbuhan Pinus dari Ekstrak Etil Asetat. Jurnal Ilmiah Farmasi, 12(2), 27-35.

Departemen Kesehatan Republik Indonesia. (2000). Parameter standar umum ekstrak tumbuhan obat. Jakarta: Direktoral Jendral Pengawasan Obat dan Makanan.

Djamal, R. (2010). Prinsip-prinsip Dasar Isolasi dan Identifikasi. Padang: Universitas Baiturrahmah.

Harborne, J. . (1987). Metode Fisikokimia Penuntun Cara Modern Menganalisis Tumbuhan. Bandung: ITB.

Kusmiyati, Aznam, N., \& Handayani, S. (2011). Isolasi dan Identifikasi Zat Aktif Ekstrak Metanol Rimpang Kunyit Putih ( Curcuma mangga Val ) Fraksi Etil Asetat. Jurnal Ilmiah Kefarmasian, 1(17), 1-10.

Kusuma, A. M., Sulistyo, A. N., Susanti, \& Sabikis. (2012). Aktivitas Penghentian Pendarahan Luar Ekstrak Etanol Daun Berenuk(Crescentia cujete L.) Secara InVivo.

Kusuma, A. M., Susanti, \& Akbariani, G. (2014). Potensi Sitotoksik Ekstrak Etanol Daun Berenuk (Crescentia cujete L.) Terhadap Sel Kanker. Farmasi Sains, 2.

Permadi, A., Sutanto, \& Wardatun, S. (2012). Perbandingan Metode Ekstraksi Bertingkat dan Tidak Bertingkat Terhadap Flavonoid Total Herba Ciplukan (physalis angulata,L) Secara Kolorimetri, 1-10.

Priyanto, A. (2013). Isolasi Senyawa Aktif Antioksidan dari Fraksi Etil Asetat Tumbuhan PakuNephrolepis falcata ( Cav .) C . Chr (Skripsi). Jakarta: Fakultas Kedokteran dan Ilmu Kesehatan Universitas Negeri Syarif Hidayatullah.

Sjamsul, A. A. (1986). Kimia Organik Bahan Alam. Jakarta: Departemen Pendidikan dan Kebudayaan.

Sudarmadji, S., Suhardi, \& Haryono, B. (1998). Analisis Untuk Bahan Makanan dan Pertanian. yogyakarta: Universitas Gadjah Mada. 